\title{
Regulation of Activation Induced Deaminase (AID) \\ by estrogen
}

\begin{abstract}
Siim Pauklin ${ }^{1, *}$
${ }^{1}$ Anne McLaren Laboratory for Regenerative Medicine, Wellcome Trust-Medical

Research Council Cambridge Stem Cell Institute, University of Cambridge, Cambridge, UK.
\end{abstract}

*Corresponding author: S. Pauklin, email: sp579@cam.ac.uk

Running title: AID regulation by estrogen 


\title{
Chapter 1
}

\section{Regulation of Activation Induced Deaminase (AID)}

\author{
by estrogen
}

\section{Siim Pauklin}

\section{Summary}

Regulation of Activation Induced Deaminase (AID) by the hormone estrogen has important implications for understanding adaptive immune responses as well as the involvement of AID in autoimmune diseases and tumorigenesis. Here I describe the general laboratory techniques for analyzing AID expression and activity induced by estrogen, focusing on the isolation and preparation of cells for hormone treatment and the subsequent analysis of AID responsiveness to estrogen at the RNA level and for determining the regulation of AID activity via estrogen by analyzing Ig switch circle transcripts and mutations in switch region loci.

Key words: Activation induced deaminase, AID, estrogen, adaptive immune responses, splenic B-cells, Ig switch circle transcripts, somatic hypermutations, autoimmune diseases. 


\section{Introduction}

Infection triggers an immune response, which aims to specifically target and remove the source of the infection from the organism while keeping its own tissues unharmed. Interestingly, it has been noted that female mice produce more antibody than male mice after immunization $(1,2)$ and that the immune responses in human display a similar sexual dimorphism that is characterized by a quicker and stronger humoral immune response in females than in males (3).

The differences in immune responses seem to be partly mediated by hormone levels in vivo, since systemic sex hormone treatment or castration in mice converts the immune responses more similar to that of the opposite sex $(4,5)$. Furthermore, an important factor in the susceptibility of various human autoimmune diseases is the hormonal status of the patient, which can affect the activity of B-lymphocytes (6-8). Female sex biases of over $80 \%$ have been reported in various autoimmune diseases including Sjogren's syndrome, lupus and scleroderma (6), while other common diseases such as myasthenia gravis, rheumatoid arthritis (RA) and multiple sclerosis (MS) have a sex distribution of $60-75 \%$ women $(6,9)$. Altogether, the increased prevalence of autoimmune disease in women, the sexual dimorphism of the immune response, and the modulatory effects of sex steroids like estrogen on the immune function in vitro suggest their involvement in mediating these sex differences. Indeed, estrogen receptors (ER $\alpha$ and $\beta$ ) are expressed not only in reproductive tissues but also in multiple other cell types, including cells of the immune system such as Blymphocytes (10-13).

One of the activative effects on B-cells by the hormone estrogen is mediated via its stimulatory effects on Activation Induced DNA deaminase (AID) (14), an enzyme that is necessary for diversification of the antibody repertoire by inducing somatic 
hypermutation and Ig class switch recombination via DNA deamination $(15,16)$. Estrogen has been shown to induce the expression of AID in B-cells and thereby enhance AID-mediated downstream processes including Ig class switching. Hence, AID induction by estrogen is important for understanding adaptive immune responses in physiological conditions but also suggests its involvement in harmful autoimmune processes (14). Due to the mutagenic activities of AID on DNA, these regulatory mechanisms could also have important implications for tumorigenesis in estrogenresponsive tissues other than B-cells (17). Here I describe the application of basic methods for studying the interconnection of estrogen and AID expression and activity in mouse splenic B-cells at the RNA level as well as switch circle transcripts and mutations in Ig switch region loci. I also highlight some of the technical nuances in working with estrogen, which are important to keep in mind for a successful application of these techniques for determining the function of estrogen as a regulator of AID in B-cells.

\section{Materials}

\subsection{Reagents}

Reconstitute all reagents using sterile DAPC-treated water or sterile DMSO.

1. Lipopolysaccharide (LPS, Sigma, UK) at $25 \mu \mathrm{g} / \mathrm{ml}$.

2. Mouse IL4 (R\&D Systems Europe Ltd, UK) at $50 \mathrm{ng} / \mathrm{ml}$.

3. Human transforming growth factor (TGF) $\beta 1$ (R\&D Systems Europe Ltd, UK) at $20 \mathrm{ng} / \mathrm{ml}$.

4. The concentrations of estrogen [17- $\beta$-estradiol (Sigma, UK)] depend on the experiment and ranges between 1-100 ng/ml (see Table 1), while Tamoxifen 
(Sigma, UK) can be used as an antagonist of estrogen at $50 \mathrm{nM}$. Hormone stocks are prepared in DMSO at a concentration of $100 \mathrm{mM}$, this is then diluted in DMSO to give $1000 \mathrm{x}$ stock solutions, and final dilutions are made in media (final DMSO concentration is less than $0.1 \%$ ). Hormone stocks are kept at $-80^{\circ} \mathrm{C}$, other reagents at either $-20{ }^{\circ} \mathrm{C}$ or $4{ }^{\circ} \mathrm{C}$ according to manufacturer's guidance. Prepare $0.1 \%$ BSA in PBS and filter sterilize the solution prior to use.

\subsection{Mouse tissue.}

Mouse tissue samples are derived from freshly sacrificed 8-12 week old female unplugged BALB/c mice. Mouse tissue is dissected and passed through cell strainers prior to hormone-depletion and estrogen treatment.

\section{Methods}

\subsection{Isolation of mouse splenic B-cells.}

1. Freshly isolated mouse spleens are transferred to a tube containing $30 \mathrm{ml}$ of RPMI $1640+$ Glutamax with $10 \%$ FCS preheated to $18-25^{\circ} \mathrm{C}$.

2. Spleens are sterilized by placing them twice into $70 \%$ ethanol for 1 second and then into media.

3. Tissues are then transferred to a wet $70 \mu \mathrm{m}$ cell strainer on top of a $50 \mathrm{ml}$ tube.

4. Cells are macerated through the filter using the back of a syringe plunger.

5. The filter is rinsed twice with $5 \mathrm{ml}$ RPMI 1640 10\% FCS solution.

6. The tube is filled with cold RPMI 1640 10\% FCS and centrifuged at $800 \mathrm{rpm}$ at 4 ${ }^{\circ} \mathrm{C}$ for 10 minutes. 
7. Supernatant is discarded and cells resuspended in $5 \mathrm{ml}$ room temperature RPMI 1640 1\% FCS.

8. The cells suspension is carefully pipetted on $7 \mathrm{ml}$ Lympholyte M (Cedarlane Laboratories Limited, Canada) in a $15 \mathrm{ml}$ tube.

9. The sample is centrifuged at $800 \mathrm{rpm}$ for 20-30 minutes to remove erythrocytes.

10. The interphase with B-cells is collected into a fresh tube (see Note 1).

11. After filling the tube with RPMI 1640 1\% FCS, cells are centrifuged at $800 \mathrm{rpm}$ for 10 minutes and the supernatant removed, leaving 2-3 $\mathrm{ml}$ of media on the cells (see Note 2)

12. $120 \mathrm{U}$ of DNAse I (Roche, UK) is added per $1 \mathrm{ml}$ cell suspension, mixed gently and incubated on a rotator for 15 minutes at RT. The suspension is filtered through a $70 \mu \mathrm{m}$ cell strainer and counted for leucocytes to obtain the total cell number.

13. The tube is filled with cold RPMI 1640 1\% FCS and centrifuged at $800 \mathrm{rpm}$ at 4 ${ }^{\circ} \mathrm{C}$ for 10 minutes.

14. Leucocytes are suspended in PBS with $0.1 \%$ BSA $\left(1 \times 10^{7}\right.$ per $\left.100 \mu \mathrm{l}\right)$ and transferred to a $15 \mathrm{ml}$ tube.

15. Mouse splenic B-cells are isolated with reagents from the Mouse B-cell Negative Isolation Kit (Dynal Biotech, Norway). $20 \mu$ heat inactivated FCS per $1 \times 10^{7}$ leucocytes is added followed by the addition of $20 \mu \mathrm{l}$ of Antibody Mix per $1 \times 10^{7}$ cells.

16. The mix is incubated for 20 min at $4{ }^{\circ} \mathrm{C}$ (see Note 3 ).

17. The cells are then washed in $2 \mathrm{ml}$ sterile PBS $0.1 \%$ BSA per $1 \times 10^{7}$ leucocytes and centrifuged at $800 \mathrm{rpm}$ at $4{ }^{\circ} \mathrm{C}$ for 10 minutes. 
18. Supernatant is removed and cells resuspended in $800 \mu \mathrm{PBS} 0.1 \%$ BSA per $1 \mathrm{x}$ $10^{7}$ leucocytes.

19. Mouse Depletion Dynabeads are washed in PBS 0.1\% BSA before adding $200 \mu 1$ per 1 x $10^{7}$ leucocytes. Cells were incubated for $15 \mathrm{~min}$ at RT with gentle rotation.

20. Bead-captured cells are resuspended and $1 \mathrm{ml}$ PBS 0.1\% BSA added per $1 \times 10^{7}$ leucocytes.

21. The tube is placed in the magnet for approximately 2 minutes before transferring the supernatant with isolated mouse B-cells into a new tube.

22. Centrifuge cells at $800 \mathrm{rpm}$ at $4{ }^{\circ} \mathrm{C}$ for 5 minutes and remove PBS $0.1 \%$ BSA from the cell pellet.

23. In the next stage, mouse splenic B-cells are depleted from hormones as described in 3.2 .

\subsection{Hormone depletion from cells.}

1. Opti-MeM Reduced Serum Medium is supplemented with: Charcoal Stripped Fetal Bovine Serum (Invitrogen Ltd, UK); Non-essential amino acids (final concentration and Sigma, UK catalog number): L-Alanine (8.9 mg/ml - A7469); L-Asparagine (15.0 mg/ml - A4159); L-Aspartic Acid (13.3 mg/ml - A4534); LGlutamic Acid (14.7 mg/ml - G8415); Glycine (7.5 mg/ml - G7126); Proline (11.5 mg/ml - P5607; L-Serine (10.5 mg/ml - S2600). Filter-sterilize the media before use (see Note 4 and Note 5).

2. Pre-warm media at $37^{\circ} \mathrm{C}$ before resuspending cells in it.

3. Cells are resuspended gently in sterile Opti-MeM Reduced Serum Medium (Invitrogen Ltd, UK) supplemented with 10\% Charcoal Stripped Fetal Bovine 
Serum and non-essential amino acids.

4. Cells are incubated for 24 - $72 \mathrm{~h}$ (see 3.3) in hormone-depleted serum at a concentration of 250,000 cells/ml (see Note 6 and Note 7).

\subsection{Time and concentration of estrogen used during various experiments.}

A list of different concentrations of estrogen and the time of cell treatment for various experiments is indicated in Table 1 (see Note 8). It is recommended to add estrogen freshly to media (see Note 9).

Table 1. Treatment of cells with hormones.

\begin{tabular}{|l|l|l|l|l|}
\hline \multicolumn{1}{|c|}{ Experiment } & \multicolumn{1}{|c|}{ Cells } & Depletion (h) & \multicolumn{1}{c|}{ [nM] } & Treatment (h) \\
\hline AID mRNA & B-cells & 24 & $0.1-1,000$ & $1-8$ \\
\hline $\begin{array}{l}\text { Mutations in switch } \\
\text { regions }\end{array}$ & B-cells & 24 & $10-50$ & 6 days \\
\hline CSR (switch circle) & B-cells & 24 & $1-50$ & 48 \\
\hline
\end{tabular}

\subsection{Analysis of AID mRNA induction in response to estrogen treatment.}

1. RNA is extracted from splenic B-cells using the RNeasy Mini kit (Qiagen, Germany) according to manufacturer's instructions. RNA is eluted with $30 \mu \mathrm{l}$ of RNase-free water by centrifuging the column at 13,000 rpm for 1 minute (see Note 10).

2. RNA concentration is measured and the samples stored at $-80{ }^{\circ} \mathrm{C}$ until cDNA synthesis (see Note 11). 
3. cDNA synthesis is performed as follows: $2.5 \mu \mathrm{g}$ of total RNA is denatured at $70{ }^{\circ} \mathrm{C}$ for $2 \mathrm{~min}$ and then placed on ice, before adding $5 \mathrm{x}$ first strand buffer, DTT to a final concentration of $5 \mathrm{mM}$, dNTPs to a final concentration of $0.4 \mathrm{mM}$ each, 0.1 $\mu \mathrm{g}$ oligo dT primer (Invitrogen Ltd, UK) and/or $2.5 \mu \mathrm{g} \mathrm{d}(\mathrm{N})_{10}$ random primers (Promega, UK), 8 U RNase OUT (Invitrogen Ltd, UK), 200 U Superscript III reverse transcriptase (Invitrogen Ltd, UK) and the appropriate quantity of RNase free $\mathrm{H}_{2} \mathrm{O}$ to a $20 \mathrm{ul}$ reaction. This is incubated at $37{ }^{\circ} \mathrm{C}$ for $10 \mathrm{~min}, 50{ }^{\circ} \mathrm{C}$ for 40 min and then $55{ }^{\circ} \mathrm{C}$ for $10 \mathrm{~min} .80 \mathrm{ul}$ of sterile $\mathrm{H}_{2} \mathrm{O}$ is added to the cDNA before incubating at $100{ }^{\circ} \mathrm{C}$ for $2 \mathrm{~min}$.

4. Analyse gene expression by quantitative real time PCR (Q-PCR), first by confirming the responsiveness of cells to estrogen is determined by Q-PCR of GREB1 (gene regulated by breast cancer 1), a known estrogen-responsive gene (18) (see Note 12). The Q-PCR reaction is as follows: $10 \mu$ of SYBRGreen PCR (Qiagen, Germany) reaction mixture is added to $9 \mu$ of RNase free water and primers (GREB1_forward 5'-TCCGAGTTCAGAGGTCGGC-3' and GREB1_reverse 5'-GTCCTACCTGTTGAGCTCCCACT-3') with a final concentration of $0.5 \mu \mathrm{M} .1 \mu \mathrm{l}$ of cDNA is added to the PCR reaction. First, reaction is incubated at $50{ }^{\circ} \mathrm{C}$ for $2 \mathrm{~min}$, then at $95{ }^{\circ} \mathrm{C}$ for $15 \mathrm{~min}$ followed by 40 cycles of melting at $95{ }^{\circ} \mathrm{C}$ for 30 seconds, primer annealing at $56{ }^{\circ} \mathrm{C}$ for 30 seconds and extension at $72{ }^{\circ} \mathrm{C}$.

5. AID expression is analysed by Q-PCR primers Aid_Forward 5'AACCCAATTTCAGATCGCG-3' and Aid_Reverse AGCGGTTCCTGGCTATGATAAC-3’.

6. GAPDH housekeeping gene is amplified with Q-PCR primers GAPDH_Forward 5’-GCACAGTCAAGGCCGAGAAT-3' and GAPDH_Reverse 5’- 
GCCTTCTCCATGGTGGTGAA-3’ for normalizing gene expression across all samples (Figure 1).

\subsection{Circle transcript detection by RT-PCR in mouse B-cells upon estrogen}

\section{treatment.}

1. Place isolated splenic B-cells into 12-well plates in $1 \mathrm{ml}$ of hormone-free medium with supplements.

2. Stimulate isolated splenic B-cells for up to $72 \mathrm{~h}$ with LPS + IL4 for inducing switching to IgG1 and IgE, LPS + TGF- $\beta$ for switching to IgA and LPS for switching to IgG3.

3. Hormones are added to the cells together with LPS and cytokines in fresh media.

4. After hormone treatment, collect cells, isolate RNA and synthesize cDNA as described above.

5. Use Q-PCR for analyzing the relative amounts of circle transcripts. Primers that are used for detecting IgG1 (19), IgG3, IgA (20) and IgE (21), are listed in Table 2.

Table 2. Primers used for detecting circle transcripts.

\begin{tabular}{|l|l|l|}
\hline Subclass & Orientation & Sequence \\
\hline IgG1 & Forward & 5'-TCGAGAAGCCTGAGGAATGTG-3' \\
\hline IgG1 & Reverse & 5'-GAAGACATTTGGGAAGGACTGACT-3' \\
\hline IgG3 & Forward & 5'-TGGGCAAGTGGATCTGAACA-3' \\
\hline IgG3 & Reverse & 5'-AATGGTGCTGGGCAGGAAGT-3' \\
\hline IgA & Forward & 5'-CCAGGCATGGTTGAGATAGAGATAG-3' \\
\hline IgA & Reverse & 5'-AATGGTGCTGGGCAGGAAGT-3' \\
\hline IgE & Forward & 5'-TTGGACTACTGGGGTCAAGG-3' \\
\hline
\end{tabular}




\begin{tabular}{|l|l|l|}
\hline IgE & Reverse & 5'-CAGTGCCTTTACAGGGCTTC-3' \\
\hline
\end{tabular}

6. Use Q-PCR for analyzing circle transcripts as follows: $10 \mu 1$ of SYBRGreen PCR (Qiagen, Germany) reaction mixture is added to $9 \mu 1$ of RNase free water and forward/reverse primers with a final concentration of $0.5 \mu \mathrm{M} .1 \mu \mathrm{l}$ of cDNA is added to the PCR reaction. First, reaction is incubated at $50{ }^{\circ} \mathrm{C}$ for $2 \mathrm{~min}$, then at $95{ }^{\circ} \mathrm{C}$ for 15 min followed by 40 cycles of melting at $95{ }^{\circ} \mathrm{C}$ for 30 seconds, primer annealing at $56{ }^{\circ} \mathrm{C}$ for 30 seconds and extension at $72{ }^{\circ} \mathrm{C}$.

\subsection{Analysis of mutations in switch regions in response to estrogen treatment.}

1. Genomic DNA is isolated from cells using PUREGENE products for Genomic DNA Isolation (Gentra Systems, USA) according to manufacturer's recommendations. $50 \mu \mathrm{l}$ of TE ( $\mathrm{pH} 8.0$ ) is added to DNA pellets and left to rehydrate overnight at $\mathrm{RT}$ before storing the samples at $-20^{\circ} \mathrm{C}$.

2. The switch region loci (the $\mathrm{S} \gamma 3$ region is described here as an example) from genomic DNA are PCR amplified as follows: 50 ng of DNA is added to a $50 \mu \mathrm{l}$ PCR reaction that included the forward primer for $\mathrm{S} \gamma 3$ region $\mathrm{g} 3.2 \mathrm{~F}$ (5'gcgaattcTTGCAACTCC-TAAGAGGAAAGATCCC-3') and reverse primer for Sy3 region g3.2R (5’-gcggatcCAGCCTGGTCC-CTACACTCCTAACAAC-3’) (22) at $20 \mu \mathrm{M}, 10 \mathrm{x}$ buffer, 10x PCR enhance, dNTP's each at $0.4 \mathrm{mM}$ and $2.5 \mathrm{U}$ of Pfu Turbo $\mathrm{R}^{\circ} \mathrm{DNA}$ polymerase.

3. The reaction is initially denatured at $94{ }^{\circ} \mathrm{C}$ for $1 \mathrm{~min}$, followed by 9 cycles of denaturation at $94{ }^{\circ} \mathrm{C}$ for 30 seconds, decreasing annealing temperature from $68{ }^{\circ} \mathrm{C}$ by $1{ }^{\circ} \mathrm{C}$ every cycle, extension at $72{ }^{\circ} \mathrm{C}$ for $2 \mathrm{~min}$. Thereafter, 35 cycles denaturation at $94{ }^{\circ} \mathrm{C}$ for 30 seconds, annealing at $63{ }^{\circ} \mathrm{C}$ and extension at $72{ }^{\circ} \mathrm{C}$ for 
$2 \mathrm{~min}$ is performed, before a final extension at $72{ }^{\circ} \mathrm{C}$ for 5 min to generate a $750 \mathrm{bp}$ PCR product.

4. PCR fragments are cloned into TOPO vector using Zero Blunt TOPO PCR Cloning Kit (Invitrogen, UK) according to manufacturer's guidance. Cells are plated on LB plates with kanamycin and grown at $37^{\circ} \mathrm{C}$ overnight.

5. Individual bacterial colonies from LB plates with antibiotics are picked into separate wells of the 96-well plates containing $1.2 \mathrm{ml}$ of LB medium.

6. The plates are covered with an adhesive sealing film (ThermalSeal, Sigma, UK) with aeration holes and incubated overnight at $37^{\circ} \mathrm{C}$ with constant rocking at 1300 rpm.

7. The bacteria are pelleted at 3,000 rpm for $15 \mathrm{~min}$, the supernatant decanted and plates stored at $-80{ }^{\circ} \mathrm{C}$ until mini-preparation and sequencing.

8. Mini-preparation is performed with QIAprep Spin Miniprep Kit according to manufacturer's guidelines.

9. Sequencing is performed with M13 forward and M13 reverse primers, followed by sequence alignment to the parental switch region sequence (see Note 13).

10. Mutations in the switch region sequence are validated by their presence in both forward and reverse sequencing reactions.

\section{Notes}

1. The efficiency of separating erythrocytes from other cells can be visually assessed by the color of the interphase cell pellet, which will be white in the 
absence of erythrocytes, while the inefficient separation of erythrocytes will maintain its red color.

2. After collecting the cells from the interphase, it is important to wash the cells with media as described, for removing the lympholyte M. Otherwise, the cell survival will be decreased.

3. Rotating at $4{ }^{\circ} \mathrm{C}$ improves antibody binding to the cells and hence the total purity of splenic B-cells.

4. Do not use phenol red as a pH indicator in the media, because this reagent can activate estrogen receptors and hence will mask the specific effects of estrogen stimulation.

5. Do not use conventional serum in your media, because it will contain hormones including estrogen that will mask the specific effects of estrogen stimulation in your samples. It is recommended to use Charcoal Stripped Fetal Bovine Serum for analyzing the effects of estrogen stimulation in B-cells and other tissues.

6. Usually, hormone depletion of mouse splenic B-cells should be performed for 24 hours, followed by treatment with estrogen in combination of LPS, IL4 or other cytokines for activating B-cells. A convenient format for such experiments is a 24-well plate and using 250,000-500,000 cells / well in $1 \mathrm{ml}$ of media.

7. If hormone depletion is performed samples other than primary cells such as mouse or human cell lines, the cells can be depleted from hormones for up to $72 \mathrm{~h}$ prior to estrogen treatment. Since each cell line has different characteristics of estrogen receptor alpha and beta expression levels, a longer than $24 \mathrm{~h}$ hormone depletion is recommended particularly for cancer lines 
with high levels of estrogen receptor expression. This should be determined with experimental optimization of the treatment conditions.

8. Aliqout estrogen stocks to smaller volumes (e.g. 25ul) in separate tubes and store them at $-80{ }^{\circ} \mathrm{C}$. Avoid repeated freezing and thawing of the stocks.

9. Add estrogen to media freshly every day since estrogen in not stable in media for a prolonged time. Tamoxifen can be used as an antagonist of estrogen in the experiments.

10. To avoid any possible degradation of RNA in samples, wipe the bench and pipettes with RNase Away (Life Technologies) prior to starting the process. Use RNase free tubes and RNAse free water. The integrity of RNA can be confirmed by running it on a $1 \%$ agarose gel and visualized by Ethidium bromide with UV.

11. Avoid repeated freezing and thawing of RNA samples, which will decrease RNA integrity.

12. The primers for Q-PCR should be designed, using $60{ }^{\circ} \mathrm{C}$ as the Tm and $150 \mathrm{bp}$ as the length of the PCR product.

13. The switch region locus should be sequenced also in the isolated splenic Bcells prior to cytokine stimulation, to obtain the unmutated parental sequence that can be used as a template for sequence alignments.

\section{Acknowledgement}

S.P. was supported by FEBS long-term fellowship.

\section{References}

1. Weinstein Y, Ran S, \& Segal S (1984) Sex-associated differences in the regulation of immune responses controlled by the MHC of the mouse. $J$ Immunol 132(2):656-661. 
2. Eidinger D \& Garrett TJ (1972) Studies of the regulatory effects of the sex hormones on antibody formation and stem cell differentiation. J Exp Med 136(5):1098-1116.

3. Butterworth M, McClellan B, \& Allansmith M (1967) Influence of sex in immunoglobulin levels. Nature 214(5094):1224-1225.

4. Bebo BF, Jr., Schuster JC, Vandenbark AA, \& Offner H (1999) Androgens alter the cytokine profile and reduce encephalitogenicity of myelin-reactive $T$ cells. J Immunol 162(1):35-40.

5. Bebo BF, Jr., et al. (2001) Low-dose estrogen therapy ameliorates experimental autoimmune encephalomyelitis in two different inbred mouse strains. J Immunol 166(3):2080-2089.

6. Whitacre CC (2001) Sex differences in autoimmune disease. Nat Immunol 2(9):777-780.

7. Kamradt T \& Mitchison NA (2001) Tolerance and autoimmunity. $N$ Engl $J$ Med 344(9):655-664.

8. Christen U \& von Herrath MG (2004) Initiation of autoimmunity. Curr Opin Immunol 16(6):759-767.

9. Ermann J \& Fathman CG (2001) Autoimmune diseases: genes, bugs and failed regulation. Nat Immunol 2(9):759-761.

10. Tornwall J, Carey AB, Fox RI, \& Fox HS (1999) Estrogen in autoimmunity: expression of estrogen receptors in thymic and autoimmune T cells. $J$ Gend Specif Med 2(5):33-40.

11. Peeva E, Venkatesh J, \& Diamond B (2005) Tamoxifen blocks estrogeninduced B cell maturation but not survival. J Immunol 175(3):1415-1423.

12. McMurray R, Keisler D, Kanuckel K, Izui S, \& Walker SE (1991) Prolactin influences autoimmune disease activity in the female B/W mouse. $J$ Immunol 147(11):3780-3787.

13. Gruber CJ, Tschugguel W, Schneeberger C, \& Huber JC (2002) Production and actions of estrogens. $N$ Engl J Med 346(5):340-352.

14. Pauklin S, Sernandez IV, Bachmann G, Ramiro AR, \& Petersen-Mahrt SK (2009) Estrogen directly activates AID transcription and function. J Exp Med 206(1):99-111.

15. Muramatsu M, et al. (2000) Class switch recombination and hypermutation require activation-induced cytidine deaminase (AID), a potential RNA editing enzyme. Cell 102(5):553-563.

16. Petersen-Mahrt SK, Harris RS, \& Neuberger MS (2002) AID mutates E. coli suggesting a DNA deamination mechanism for antibody diversification. Nature 418(6893):99-103.

17. Petersen-Mahrt SK, Coker HA, \& Pauklin S (2009) DNA deaminases: AIDing hormones in immunity and cancer. J Mol Med (Berl) 87(9):893-897.

18. Ghosh MG, Thompson DA, \& Weigel RJ (2000) PDZK1 and GREB1 are estrogen-regulated genes expressed in hormone-responsive breast cancer. Cancer Res 60(22):6367-6375.

19. Reina-San-Martin B, et al. (2003) H2AX is required for recombination between immunoglobulin switch regions but not for intra-switch region recombination or somatic hypermutation. J Exp Med 197(12):1767-1778.

20. Kinoshita K, Harigai M, Fagarasan S, Muramatsu M, \& Honjo T (2001) A hallmark of active class switch recombination: transcripts directed by I promoters on looped-out circular DNAs. Proc Natl Acad Sci U S A 98(22):12620-12623. 
21. Lumsden JM, et al. (2004) Immunoglobulin class switch recombination is impaired in Atm-deficient mice. J Exp Med 200(9):1111-1121.

22. Xue K, Rada C, \& Neuberger MS (2006) The in vivo pattern of AID targeting to immunoglobulin switch regions deduced from mutation spectra in msh2-/ung-/- mice. J Exp Med 203(9):2085-2094.

\section{Figure legends}

Figure 1. The effects of estrogen on AID mRNA in splenic B-cells. (A) Changes in AID mRNA in response to estrogen treatment in stimulated B-cells. Isolated mouse splenic B-cells were stimulated with LPS and IL4 and treated with different physiological concentrations of estrogen for $8 \mathrm{~h}$. (B) AID mRNA in response to estrogen treatment in un-stimulated B-cells, after $8 \mathrm{~h}$ treatment with physiological concentrations of estrogen. Data is representative of three independent experiments and error bars indicate standard deviations from the average. DMSO is set to 1, and treatments are represented as relative change to DMSO. NT - not treated. 